\title{
Commentary
}

\section{Home quarantine: why the preference}

\author{
Sabira Aalia Dkhar, Ruqia Quansar*
}

Department of Community Medicine, Government Medical College, Srinagar, Jammu and Kashmir, India

Received: 23 April 2020

Revised: 03 June 2020

Accepted: 04 June 2020

\section{*Correspondence:}

Dr. Ruqia Quansar,

E-mail: ruqiaquansar@gmail.com

Copyright: (C) the author(s), publisher and licensee Medip Academy. This is an open-access article distributed under the terms of the Creative Commons Attribution Non-Commercial License, which permits unrestricted non-commercial use, distribution, and reproduction in any medium, provided the original work is properly cited.

\section{INTRODUCTION}

In the existing pandemic of COVID-19, we have been hearing a lot about quarantine. Quarantine is to isolate from normal relations and routine activities or communication and is recommended for apparently healthy people who may have been exposed to the virus (suspects) and may potentially transmit the same to others. ${ }^{1}$ These healthy individuals may fall sick due to possible exposure and are therefore advised to go on selfquarantine or may be ordered by state or local administration to stay at home or in facilities like hospitals (public or private), hotels, schools, worship places etc. to isolate them from normal relations in order to prevent transmission of virus to others. Quarantine can be unpleasant and lasts for 14 days which is the presumed incubation period for the virus. ${ }^{2}$

While most of the primary and secondary contacts are kept under quarantine in the facility rather than home, and the risk of getting infected with virus is high in such facility due to improper segregation of these contacts. All together it is a hardship both emotional as well as financial and the process may be a little frightening to most of the suspects undergoing the same however among all available options of quarantine, home quarantine can be assumed as the most pleasant option when one thinks of the benefits it offers.

\section{COMFORT OF HOME}

When asked to seclude yourself it becomes harder than it sounds, it may sound like a vacation from reality an ideal time to binge and catch up on sleep. But there are practical and logistic challenges as it's not easy to lock yourself away from friends and family, being quarantine can be one's own decision to protect own self and the family or it may be because they are bound by state or local guidelines. Being at home gives one calmness and a relaxed feeling having been well adapted to the environment, one has less to complaint.

\section{COMPLIANCE}

It is expected that those in facility quarantine have more chances of being rebellious because putting suspects in a facility quarantine can give them a feeling of being ill, jailed or locked away as they may not have the other liberties like those in home quarantine thus leaving them more stressed thereby leading to revolt resulting in compromise with compliance of guidelines. However, being at home does not throw any such challenges steering to higher compliance of guidelines.

\section{UTILIZATION OF HUMAN AND OTHER RELATED RESOURCES}

Once the suspects are under facility quarantine, it requires man-power, money, space and other related infrastructure to take care of those people. However when put under home quarantine and family members are well instructed on how to take care of a person who is in quarantine whilst protecting themselves; it leaves the specialized human resources used for monitoring in case of facility quarantine to be channelized for confirmed infected cases, moreover helping in utilizing the money and other infrastructure for procurement of testing kits and management of other treatment facilities.

\section{STIGMA IS LESS}

It's not something unusual if we find social norms influential and the stigma associated with the virus makes one more vulnerable to these influences thus making 
them shy away from being quarantined in common facilities and if one stays in a facility quarantine and comes out after 14 days, the social stigma that will follow will have an impact on him for long on the other hand being in home quarantine has less of such social influence. $^{3}$

\section{PREVENTION OF CROSS INFECTION}

When suspects are put under facility quarantine, they may be put along some other people, who may be asymptomatic patients of COVID-19, thus increasing the risk of non-infected suspects to acquire the same. It thus poses more threat while attempting to prevent the spread of infection. Hence, keeping the suspects under home quarantine may prevent their exposure to the asymptomatic patients and prevent them for being converted to infected patients. ${ }^{4}$

\section{ADDED CARE}

When suspects are around their loved ones it is bound that they receive added care and affection. When it comes to one's family its well understood that one may not want them to acquire the infection, hence renders a suspect to be more cautious and more particular to follow all the guidelines for quarantine.

\section{FOOD AND ENVIRONMENT}

It is a fact that an individual cannot compromise on food for long, moreover the attempts to meet the constantly changing conditions are adding to the stress of a suspect in quarantine conversely when one's food habits and environment stays the same whilst being at home, there is less apprehension of upsetting one's sentiments.

\section{PERSONALIZED MONITORING}

When family members become the primary caregivers. It is observed that they keep a keen watch and thus help attain a more individualised care.

\section{MENTAL HEALTH}

The suspects when put under facility quarantine may feel depressed, insecure and isolated, thus it is bound that their mental health will be more affected before the virus can do any harm as the feeling of anxiety, stigma and the post-traumatic stress can leave a long impact on one's mental health. ${ }^{5}$ This all can be reduced in a home quarantine as the aura around is very familiar and soothing, they don't feel dejected and thus they have a stable mental health leading to a positive impact. ${ }^{6}$

\section{GREATER INDEPENDENCE}

For a suspect at home quarantine it is rare to find opportunities like these when one gets "me time", to learn something new, spend good family time and execute the chores keeping them involved but with a sense of greater independence.

\section{WORK FROM HOME}

Once put under facility quarantine, suspects are bound to be there and with meagre available facilities they can't work remotely or even study, thus affecting their career and or studies. Nevertheless, while in home quarantine working a little on the ergonomics and setting up home office can help to be an effective tool to ensure continuity of work from the comfort of home and subsides the related stress of being in quarantine.

All of us have a responsibility to protect oneself, our families, our friends and the community we live in, we should voluntarily decide to be home quarantined, follow all the guidelines religiously and advocate it to others as well.

As the proverb says "you don't find refuge from storm; you find refuge in the storm" The bottom line is home quarantine only works to limit the spread of disease if people stick to it. How well will it work or how effective it is as compared to other measures is less certain.

\section{REFERENCES}

1. Parmet WE, Sinha MS. Covid-19 - The law and Limits of Quarantine. N Engl J Med. 2020;28(1):13.

2. Lauer SA, Grantz KH, Bi Q, Jones FK, Zheng Q, Meredith HR, et al. The Incubation Period of Coronavirus Disease 2019 (COVID-19) From Publicly Reported Confirmed Cases: Estimation and Application. Ann Intern Med. 2020;172(9):577-82.

3. Farag E, Marufu O, Sikkema R, Thani M Al, Reusken CBEM, Koopmans MPG. MERS Coronavirus at the Human - Animal Interface. Int $\mathbf{J}$ Infect Dis. 2016;45:332.

4. Adnan M, Khan S, Kazmi A, Bashir N, Siddique R. COVID-19 infection: Origin, transmission, and characteristics of human coronaviruses. J Adv Res. 2020;24:91-8.

5. Bisson JI. Post-traumatic stress disorder. Occup Med (Chic Ill). 2007;57(6):399-403.

6. Brooks SK, Webster RK, Smith LE, Woodland L, Wessely S, Greenberg N, et al. The psychological impact of quarantine and how to reduce it: rapid review of the evidence. Lancet. 2020;395(10227):912-20.

Cite this article as: Dkhar SA, Quansar R. Home quarantine: why the preference. Int J Community Med Public Health 2020;7:2865-6. 